\title{
Juveniles' Capacities to Waive Miranda Rights: An Empirical Analysis
}

\author{
Thomas Grisso†
}

Altlougl Miranda v. Arizona ${ }^{1}$ established that a criminal suspect must be warned specifically of his rights to silence and to counsel before imterrogation, whether a juvenile suspect has the legal and psychological capacities to understand these rights is subject to question. ${ }^{2}$ Doubts concerning minors' comprehension of their Miranda rights are increased by the fact that despite receiving the warnings, most juveniles in pretrial proceedings waive rather than invoke their rights. ${ }^{3}$ The validity of Miranda riglits waivers by juveniles, therefore, is a perplexing, ${ }^{4}$ significant ${ }^{5}$ issue.

Recognizing that waivers by juveniles merit special consideration and scrutiny not accorded those by adults, courts have generally followed one of two approaclies. Either they liave required an after-thefact review of all tlie circumstances attending the waiver, or they have required initial safeguards followed by a review of whcther the safeguards were effected. The first approach, adopted by the majority of jurisdictions, inandates a consideration of the "totality of the circunnstances" in determining whether a juvenile's waiver of his Miranda riglits was knowingly, intelligently, and voluntarily made. ${ }^{6}$ Thus, in assessing the validity of a waiver, courts are free to consider, inter alia,

$\dagger$ Associate Professor of Psychology, Saint Louis University. B.A. 1964, Ashland College; M.A. 1966, University of Arizona; Ph.D. 1969, University of Arizona.

1. 384 U.S. 436 (1966).

2. See, e.g., Comment, Interrogation of Juveniles: The Right to a Parent's Presence, 77 Drck. L. Rev. 543 (1972-73); Comment, The Judicial Response to Juvenile Confessions: An Examination of the Per Se Rule, 17 DuQ. L. Rev. 659 (1978-79); Comment, The Interrogated Juvenile: Caveat Confessor?, 24 Hastings L.J. 413 (1973).

3. In a recent study of a large, random sample of juvenile arrests for alleged felonies, only about $10 \%$ of the juveniles informed of their Miranda rights chose not to waive them, including less than 5\% of the juveniles 14 years of age or younger. Grisso \& Pomicter, Interrogation of Juveniles: An Empirical Study of Procedures, Safeguards, and Rights Waiver, 1 Law \& Human BEHAVIOR 321 (1977).

4. See generally In re Gault, 387 U.S. 1, 55 (1967); S. DAVIS, RIGHTS OF JUVENILES: THE Juvenile Justice System, $\$ \$ 3.12-13$ (1974); M. PAulsen \& C. Whitebread, Juvenile LaW ANd Procedure, 104-09 (1974).

5. Recent research has imdicated that police officers attempt to interrogate almost $75 \%$ of the juveniles referred to courts on felony charges. Grisso \& Pomicter, supra note 3, at 330.

6. Fare v. Michael C., 442 U.S. 707, 725-26 (1979); People v. Lara, 67 Cal. 2d 365, 432 P.2d 
the juvenile's age, intelligence, maturity, and prior experience in criminal proceedings. In 1979, in Fare v. Michael $C^{7}$ the United States Supreme Court affirmed this "totality" approach as the federal constitutional standard. Addressing for the first time the validity of a juvenile's waiver made prior to interrogation, the Court held that a determination of the voluntariness of the waiver should not be based solely on a particular procedure employed in obtaining the waiver or on a specific characteristic of the accused juvenile. ${ }^{8}$ Rather, all the circumstances of the particular case sliould be evaluated.

The second approach, developed in case law and legal commentary, ${ }^{9}$ greatly reduces the court's discretion in determining whether the waiver was in fact voluntarily made. It calls for the application of per se exclusionary rules whenever the juvenile has not been afforded specific assistance. The approach requires the presence of an "interested adult"-parent, guardian, or attorney-to advise the juvenile of his rights and of the implications of making a waiver. Waivers made without this assistance are deeined invalid. Unlike the "totahty" approach, the "per se" approach automatically excludes a waiver based on the absence of certain circumstances-i.e., on the absence of the requisite procedural safeguards.

A deterinination of the relative value of these two approaclies cannot be made without an underlying knowledge of the intellectual and emotional characteristics of juveniles. Is it valid to assume, as permitted by Fare's totahity approach, ${ }^{10}$ that juveniles with exposure to the juvenile system understand their riglits to counsel and to silence better than do juvemiles without exposure? Is the proportion of juveniles who do not understand their rights sufficient to warrant a per se approach? Are there other characteristics that are indicative of a juvenile's ability to comprehend the warnings and that should be included in judicial determinations?

To provide judges, legislators, and attorneys with the information necessary to address these issues, social scientists and lawyers at St. Louis University performed a series of empirical studies of the legal and psychological capacities of juveniles and adults to waive their $M i$ -

202, 62 Cal. Rptr. 586 (1967), cert. denied, 392 U.S. 945 (1968); State v. Hills, 354 So. 2d I86 (La. 1977); Commonwealth v. Cain, 361 Mass. 224, 279 N.E.2d 706 (1972).

7. 442 U.S. 707 (1979). A juvenile's request to speak to his probation officer was held not to be an invocation of his right against self-incrimination. See note 25 and accompanying text infra.

8. 442 U.S. at 724-26.

9. See notes $32-38$ and accompanying text infra. See also Note, Waiver in the Juvenile Court, 68 Colum. L. Rev. 1149 (1968); Comment, Interrogations of Juveniles: The Right to a Parent's Presence, supra note 2; Comment, The Interrogated Juvenile: Caveat Confessor?, supra note 2.

10. 442 U.S. at $725-26$. 
randa rights knowingly. ${ }^{11}$ This Article describes the methodology and results of two of these studies ${ }^{12}$ and discusses the necessity for the further developinent of juvenile rights. Part I discusses the assumptions underlying the totality and per se approaches, while Part II describes the methodology of the two Miranda-comprehension studies that tested these assumptions. Part III analyzes the results of the studies, concluding that juveniles younger than fifteen manifest significantly poorer comprehension than adults of comparable intelligence. Part IV urges that a per se approach which assures the suspect a nonwaivable right to counsel in preinterrogation waiver proceedings be adopted for both younger and older juveniles.

\section{I}

\section{Alternate Approaches to Protecting the Rights of JUVENILES \\ A. A Need for Special Protection}

In 1967, In re Gault ${ }^{13}$ extended to juveniles in delinquency proceedimgs ${ }^{14}$ the same rights to legal counsel and to avoid self-incrimination that had been accorded adults in custody by Miranda. Decided the year before, Miranda had held that adults apprehended by the police must be informed, before interrogation, of the elements of the right to remain silent and of the right to counsel. The Court had prescribed the form, wording, and noncoercive approaches permitted the police in mforming suspects of these rights and in seeking a waiver. Any waiver not "voluntarily, knowingly, and intelligently" made would be invalid. ${ }^{15}$

11. Results from all five studies in the project are reported in T. Grisso, Juveniles' WaIver of RIGHTS: Legal AND PsychologiCAL COMPETENCE (1981) (in press). The project research staff obtained consultation from the legal staff of the National Juvenile Law Center throughout the three-year period involved. Data collection was accomphished with the cooperation of the St. Louis County Juvenile Court and the Magdala Foundation (adult ex-offenders). The project was completed with a research grant (MH-27849, Competence of Juveniles to Waive Rights) from the Center for Studies of Crime and Delinquency, National Institute of Mental Health, HEW.

12. Study I (measuring comprehension of words and phrases) and Study II (measuring comprehension of the function and significance of the rights) are described in Part II of this Article. See notes 53-56 and accompanying text infra, notes 64-67 and accompanying text infra.

13. 387 U.S. 1 (1967).

14. Gault extended to juveniles the rights to counsel and to avoid self-mcrimination at critical stages in the legal process, yet it did not specifically decide their necessity in pretrial police interrogation. Their application at this stage has been assumed by most post-Gault courts addressing the issue. For a discussion of the case law supporting this requircment, see P. P1ERSMA, J. Ganousis, A. Volenik, H. Swanger, \& P. Connell, Law and Tactics in Juvenile Cases, 70-71 (3d ed. 1977) [hereinafter cited as LAW AND TACTics]. But see State v. R.W., 115 N.J. Super. 286, 279 A.2d 709 (1971).

15. As for the procedural safeguards to be employed, unless other fully effective means are devised to inform accused persons of their right of silence and to assure a contimuous 
While the Miranda requirements were estabhshed as the minimum standard for the protection of juvenile rights, Justice Fortas' majority opinion in Gault recognized that even greater protection might be required where juveniles are involved, since their immaturity and greater vulnerability place them at a greater disadvantage in their dealings with the police. ${ }^{16}$ Although juveniles can waive their rights, the waivers inust be carefully scrutinized to assure that they are truly voluntary. 17

Both the totahity and the per se responses have developed out of this recognized need for special caution in the interrogation of juveniles. The two approaches, however, contrast inarkedly due to differing perceptions of the balance between the state's interest in effective police investigations and the steps necessary to ensure the voluntariness of juvenile waivers. The totality approach is intended to allow a full consideration of the circumstances attendant to a juvenile's maturity or immaturity. It permits a court to exercise discretion in making an evaluation; at the same time, it minimizes interference with pohce work. In contrast, the per se approach assumes that most juveniles need special protection not afforded to adults. It is premised on a belief that the vast inajority of juveniles will not understand their rights when advised of them and that a prophylactic rule is therefore necessary. Under this theory, the problem of providing unnecessary protection for sophisticated juveniles is oversliadowed by the need to afford adequate protection to most juveniles.

\footnotetext{
opportunity to exercise it, the following measures are required. Prior to any questioning, the person must be warned that he has a right to remain silent, that any statement he does make may be used as evidence against him and that he has a right to the presence of an attorney, either retained or appointed. The defendant may waive effectuation of these rights, provided the waiver is made voluntarily, knowingly and intelligently. If, however, he indicates in any manner and at any stage of the process that he wishes to consult with an attorney before speaking there can be no questioning. Likewise, if the individual is alone and indicates in any unanner that he does not wish to be interrogated, the police may not question him. The mere fact that he may have answered some questions or volunteered some statements on his own does not deprive him of the right to refrain from answering any further inquiries until he has consulted with an attorney and thereafter consents to be questioned.
}

384 U.S. at $444-45$.

16. The Court urged: "[T]he greatest care must be taken to assure that [a uninor's] admission was voluntary, in the sense that it was not coerced or suggested, but also that it was not the product of ignorance of rights or of adolescent fantasy, fright or despair." 387 U.S. at 55. Prior to Gault, courts had operated under the theory of parens patriae. Under this theory the state assumed the parents' role in taking custody of the juvenile, interesting itself in the child's rehabilitation rather than his guilt. In exchange for this benevolent treatment the juvenile gave up many constitutioual protections accorded adults. See generally id. at 14-18.

17. Id. at 55. This comports with the earlier recognition in Haley v. Ohio, 332 U.S. 596, 599600 (1948), and Gallegos v. Colorado, 370 U.S. 49, 54-55 (1962), that in assessing the voluntariness of a waiver by a juvenile, special consideration must be given to the child's legal and psychological capacities. 


\section{B. The Totality Approach}

The validity of a juvenile's waiver of his Miranda rights has traditionally been determined by an examination of the "totality of the circumstances." 18 The court's role is to evaluate all the factors-the juvenile's cliaracteristics in light of the procedural factors surrounding the interrogation-m order to determine whether the waiver really was knowingly, intelligently, and voluntarily inade. West $\nu$. United States ${ }^{19}$ pointed to nine factors to consider. Two were personal characteristics of the juvenile-age and education-while the other seven referred to procedural considerations, such as police interrogation methods, surrounding the case. ${ }^{20}$ State $v$. White ${ }^{21}$ suggested other factors, including the juvenile's physical condition, intelligence, and experience with the police and the courts. There is no case law, however, which suggests how to evaluate all the considerations systematically. The inanner in which the factors are weighed and coinbimed has always been a inatter of judicial discretion.

The theory behind the approach is that the juvenile courts can coinpetently evaluate these considerations. Adherents clann that there is no reason courts should not be able to evaluate all the circumstances just as in any otlier case. ${ }^{22}$ Moreover, they argue that the approach enables police to deal effectively with those juveniles who clearly understand the effect of their waivers and thereby serves the public interest in swift and effective law enforcement. ${ }^{23}$

The degree to which judges can weigh these factors consistently, however, is difficult to discern. ${ }^{24}$ There are numerous combinations of factors possible and no guidelines as to how they should be weighed

18. See note 6 supra.

19. 399 F.2d 467 (5th Cir. 1968), cert. denied, 393 U.S. 1102 (1969).

20. The seven procedural matters imcluded whether or not the juvenile was informed of the charges and his rights, whether he was held incommunicado, whether he was interrogated before or after charges were filed, the methods of interrogation used, the length of interrogation, whether the accused had refused to give a statement ou prior occasions, and whether the accused gaveand later repudiated-an extrajudicial statement. Id. at 469.

21. 494 S.W.2d 687, 690 (Mo. Ct. App. 1973). Cf. Fare v. Michael C., 442 U.S. at 725 (circumstances to consider include "the juvenile's age, experience, education, background, and intelligence, and . . . whether he has the capacity to understand the warnings given him, the nature of his Fifth Amendment rights, and the consequences of waiving those rights").

22. Id; Commonwealth v. Roane, 459 Pa. 389, 394, 329 A.2d 286, 289-90 (1974) (Eagen, J., dissenting).

23. Greater flexibility in permissible pohice procedures, however, results in more ambiguity concerning a court's interpretation of those procedures. Without more structured guidelines, pohice officers can only guess how the circumstances of a speciflc case will be perceived at the trial.

24. Typically, opinions discussing the validity or invahidity of a juvenile's waiver will note several of the child's characteristics (e.g., age, intelligence) which contributed to the decision. The opinions generally do not explain the relative importance of these characteristics. A review of the relevant decisions between 1948 and 1979, however, does reveal a few trends in judicial evaluation 
and balanced. This results in almost unlimited judicial discretion. While a majority of the Supreme Court in Fare professed confidence im the ability of juvenile courts to balance all the variables in a manner that would consistently identify juveniles capable of making a meaningful waiver, ${ }^{25}$ this confidence seems misplaced given the Court's own split over the validity of the waiver at bar. ${ }^{26}$ The conflictimg weighting

of demographic factors. Note, however, that no single variable is determinative, since one variable is usually cited in conjunction with other variables.

(1) In regard to age, courts have tended to perceive an absence of the requisite understanding on the part of juveniles 12-years-old or younger. See, e.g., C.W. v. Murphy, 508 S.W.2d 520 (Mo. Ct. App. 1974); In re R., 42 A.D.2d 541, 345 N.Y.S.2d 11 (1973). They have found adequate comprehension of Miranda rights by juveniles aged 16 to 19 . See, e.g., People v. Lara, 67 Cal. 2d 365, 432 P.2d 202, 62 Cal. Rptr. 586 (1967), cert. denied, 392 U.S. 945 (1968); Doerr v. State, 348 So. 2d 938 (Fla. Dist. Ct. App. 1977); State v. Young, 220 Kan. 541, 552 P.2d 905 (1976); People v. Stannis, 41 Mich. App. 565, 200 N.W.2d 473 (1972); State v. McConnell, 529 S.W.2d 185 (Mo. Ct. App. 1975); State v. Prater, 77 Wash. 2d 526, 463 P.2d 640 (1970). Cases involving juveniles aged 13 through 15 have produced less consistent outcomes and frequent dissents. See, e.g., Gallegos v. Colorado, 370 U.S. 49 (1962); United States v. Miller, 453 F.2d 634 (4th Cir. 1972); Lopez v. United States, 399 F.2d 865 (9th Cir. 1968); Parker v. State, 351 So. 2d 927 (Ala. Crim. App. 1977); State v. Toney, 113 Ariz. 404, 555 P.2d 650 (1976); In re Estrada, 1 Ariz. App. 348, 403 P.2d 1 (1965); In re P., 7 Cal. 3d 801, 500 P.2d 1, 103 Cal. Rptr. 425 (1972); Tennell v. State, 348 So. 2d 937 (Fla. Dist. Ct. App. 1977); Williams v. State, 238 Ga. 298, 232 S.E.2d 535 (1977); Riley v. State, 237 Ga. 124, 226 S.E.2d 922 (1976); People v. Carpenter, 38 Ill. App. 3d 435, 347 N.E.2d 781 (1976); In re Morgan, 35 Ill. App. 3d 10, 341 N.E.2d 19 (1975); In re Stiff, 32 Ill. App. 3d 971, 336 N.E.2d 619 (1975); State ex rel. Holifield, 319 So. $2 d 471$ (La. Ct. App. 1975); Commonwealth v. Cain, 361 Mass. 224, 279 N.E.2d 706 (1972); In re L., 29 A.D.2d 182, 287 N.Y.S.2d 218 (1968); Cominonwealth v. Darden, 441 Pa. 41, 271 A.2d 257 (1970), cert. denied, 401 U.S. 1004 (1971).

(2) With respect to level of intelligence, courts have tended to find that juveniles with IQ scores below 75 have an inadequate understanding of their rights. See, e.g., Cooper v. Griffin, 455 F.2d 1142 (5th Cir. 1972); Thoinas v. State, 447 F.2d 1320 (4th Cir. 1971); Lynch v. Fay, 184 F. Supp. 277 (S.D.N.Y. 1960); In re P., 7 Cal. 3d 801, 500 P.2d 1, 103 Cal. Rptr. 425 (1972); People v. Baker, 9 Ill. App. 3d 654, 292 N.E.2d 760 (1973); State ex rel. Holifield, 319 So. 2d 471 (La. Ct. App. 1975); People v. Stannis, 41 Mich. App. 565, 200 N.W.2d 473 (1972); Commonwealth v. Youngblood, 453 Pa. 225, 307 A.2d 922 (1973).

(3) A juvenile's lack of prior contact with the pohce has sometimes been viewed as weighing against sufficient understanding of the Miranda warnings, especially in combination with other variables supporting this conclusion. Cooper v. Griffin, 455 F.2d 1142 (5th Cir. 1972); Simon v. Maroney, 228 F. Supp. 800 (W.D. Pa. 1964); In re P., 7 Cal. 3d 801, 500 P.2d 1, 103 Cal. Rptr. 425 (1972); Commonwealth v. Cain, 361 Mass. 224, 279 N.E.2d 706 (1972). At other times extensive prior experience has been cited as suggestive of greater understanding. See, e.g., State v. Toney, 113 Ariz. 404, 555 P.2d 650 (1976); In re Morgan, 35 Ill. App. 3d 10, 341 N.E.2d 19 (1975); State v. Prater, 77 Wash. 2d 526, 529, 463 P.2d 640, 641 (1970) (fact that a juvenile had 15 prior arrests was considered to nitigate against any error in the police officer's hurried and incomplete manner of informing the juvenile of his rights).

(4) Finally, a juvenile's level of education or hiteracy has sometimes been cited as relevant, but the decisions offer no consistent view as to how grade or reading level should be used to draw the necessary inferences. Simon v. Maroney, 228 F. Supp. 800 (W.D. Pa. 1964); Commonwealth v. Youngblood, 453 Pa. 225, 307 A.2d 922 (1973).

25. 442 U.S. at 725.

26. In Fare a 16 1/2-year-old boy, Michael C., was taken into custody on suspicion of murder. He had been on probation for four years and had served a term in a youth corrections camp under the supervision of the juvenile court. At the police station two police officers began to question him. Prior to waiving his rights, he asked to see his probation officer, who had earhier 
and assessment of the circumstances by the majority ${ }^{27}$ and Justice Powell in dissent ${ }^{28}$ underscore the extensive discretion the process vests in the courts. Such a conflict also fosters distrust of the totahty approach. ${ }^{29}$ Moreover, if it can be shown that the great majority of juveniles do not understand and appreciate their rights, yet are deemed to have waived those rights under the totahty approach, then the approach may not comport with Gault's admonition to exercise "the greatest care" in assessing the validity of juvenile waivers. ${ }^{30}$

\section{The Per Se Approach}

Soine jurisdictions, dissatisfied with the totality of the circumstances approach, have adopted per se rules requiring that an "interested" adult be present to advise a juvenile prior to the interrogation. ${ }^{31}$

advised that Michael contact him in such a situation. Id. at 733 (Powell, J., dissenting). The request was denied. When subsequently asked whether he wanted to consult an attorney, the juvenile responded, “How I know you guys won't pull no police officer in and tell me he's an attorney?" The police did not answer this question. Michael C. then agreed to talk and confessed. Id. at $710-11$.

27. The inajority found that Michael C. understood his rights:

[N]o special factors indicate that respondent was unable to understand the nature of his actions. He was a 16 1/2-year-old juvenile with considerable experience with the police. He had a record of several arrests. He had served time in a youth camp, and he had been on probation for several years. ... There is no indication that he was of insufficient intelligence to understand the rights hc was waiving, or what the consequences of that waiver would be.

Id. at 726 .

28. In his dissent Justice Powell correctly observed that the defendant's question indicates a fundamental misunderstanding of his rights. Id. at 733-34 (Powell, J., dissenting). Contrary to the majority's characterization of the circumstances he declared:

Respondent was a young person, 16 years old . . . . Although respondent had had prior brushes with the law, and was under supervision by a probation officer, the taped transcript of his interrogation-as well as his testimony at the suppression hearing-denonstrates that he was immature, emotional, and uneducated, and therefore was likely to be vulnerable to the skillful, two-to-one, repetitive style of interrogation to which he was subjected.

Id. at 733 (Powell, J., dissenting) (footnote omitted). See also id. at 730 \& n.1 (Marshall, J., dissenting) (recognizing that Michael C. did not trust the police to respect his rights).

29. See, e.g., In re Dino, 359 So. 2d 586, 591 (La.), cert. denied, 439 U.S. 1047 (1978).

30. 387 U.S. at 55 .

31. Per se exclusionary rules are not unfaniliar in waiver contexts. Miranda itself has the effect of a per se exclusion of waivers. The court stated that procedures unust be established to insure that suspects are appraised of their rights. Unless other acceptable procedures are established, the standard Miranda warnings must be given to all suspects. 384 U.S. 436, 436 (1966).

The Fifth Amendment privilege to remain silent is so fundamental to our systein of constitutional rule and the expedient of giving an adequate warning as to the availability of the privilege so simple, we will not pause to inquire in individual cases whether the defendant was aware of his rights without a warning being given. Assessments of the knowledge the defendant possessed, based on information as to his age, education, intelligence, or prior contact with authorities, can never be inore than speculation; a warning is a clearcut fact.

Id. at 468-69 (footnote omitted). When the appropriate warnings are not given, the courts are precluded from examining the circumstances to discover whether the defendant understood his rights and whether the waiver was voluntarily made. Consequently, confessions made under these 
In 1974, the Pennsylvania Supreme Court established the foundation for a per se rule in Commonwealth v. Roane. ${ }^{32}$ Roane held that the prosecution had failed to establish that the juvenile's waiver was knowing and voluntary since the boy's mother was denied her request to ineet witl her son in private. The court based its decision on a belief that a juvenile is unable to understand his rights without the advice of an interested adult, ${ }^{33}$ relying in part on the United States Supreme Court's discussion in Gallegos v. Colorado ${ }^{34}$ of the value of adult advice in ensuring the voluntariness of a juvenile's waiver. Although Roane was decided under the totality approach, the adoption of its rationale by Pennsylvania courts gradually led to the establishment of a per se requirenient. $^{35}$ In Pennsylvania, juveniles must have the opportunity to consult with an interested adult who has been informed of the minor's rights and is aware of the consequences of a waiver. ${ }^{36}$ In other states courts have adopted similar per se rules, ${ }^{37}$ while some legislatures have enacted statutes requiring automatic exclusion of confessions extracted without the advice of an interested adult. ${ }^{38}$

Under the per se approach, the courts retain limited discretion in determining whether the applicable per se requirenents lave been satisfied. Foreniost annong the criteria they must consider is whether the

circumstances are excludable per se. Similarly, if the defendant refuses to talk or requests to speak with his attorney, his statements are deemed a per se invocation of his rights, and all interrogation must cease. Id. at 444-45.

32. 459 Pa. 389,329 A.2d 286 (1974).

33. Id. at $394-95,329$ A.2d at 288 .

34. Gallegos noted:

A lawyer or an adult relative or friend could have given the petitioner the protection which his own immaturity could not. Adult advice would have put him on a less unequal footing with his interrogators. Without some adult advice against this inequality, a 14-year-old boy would not be able to know, let alone assert, such constitutional rights as he had. To allow this conviction to stand would, in effect, be to treat him as if he had no constitutional rights.

370 U.S. 49, 54-55 (1962).

Gallegos was decided on the totality approach, the presence of an interested adult being only one of the circumstances considered.

35. See, e.g., Commonwealth v. Markle, 475 Pa. 266, 270, 380 A.2d 346, 348 (1977) ("[w]hen a juvenile has not been given this opportunity for cousultation, we need not look to the totality of the circumstances to determine the voluntariness of the confession"); Commonwealth v. Smith, 472 Pa. 492, 372 A.2d 797 (1977); Commonwealth v. Gaskins, 471 Pa. 238, 369 A.2d 1285 (1977); Commonwealth v. Webster, $466 \mathrm{~Pa} .314,353$ A.2d 372 (1975); Commonwealth v. McCutchen, 463 Pa. 90, 343 A.2d 669 (1975), cert. denied, 424 U.S. 934 (1976).

36. Commonwealth v. Smith, $472 \mathrm{~Pa} .492,498-99,372$ A.2d 797, 800 (1977).

37. See, e.g., Lewis v. State, 259 Ind. 431,288 N.E.2d 138 (1972); In re K.W.B., 500 S.W.2d 275 (Mo. Ct. App. 1973). See also People v. Burton, 6 Cal. 3d 375, 491 P.2d 793, 99 Cal. Rptr. 1 (1971), where the California Supreme Court held that a juvenile's request to see his parent prior to interrogation was a per se invocation of his rights.

38. See, e.g., Colo. Rev. Stat. tit. 19-2-102, \&3(c)(1) (1978); Conn. Gen. Stat. AnN. § 46b-137(a) (West Supp. 1979); N.M. STAT. ANN. § 32-1-27(A) (1978); OKLA. STAT. ANN. tit. 10, $\S$ 1109(a) (West Supp. 1979-1980). 
adult was "interested"-genuinely concerned with the juvenile's welfare. ${ }^{39}$ They must also determine whether the adult was informed of the juvenile's rights, ${ }^{40}$ whether the adult understood those rights, ${ }^{41}$ whether the child and the adult had an adequate opportunity to confer in private, ${ }^{42}$ and whether the conference was meaningful..$^{43}$

The per se approach has been criticized by some commentators for not goimg far enough to safeguard the rights of juveniles, while others have claimed that, by imterfering with police activities, it goes too far. On the one hand, commentators have argued that requiring the presence of a parent at waiver proceedings is not sufficient; his competing interests, emotional reactions to his child's arrest, or imtellectual incapacities may interfere with his ability to provide the counsel and support needed by the child. ${ }^{44}$ This criticism ${ }^{45}$ has contributed to an emerging trend of statutory per se exclusion of confessions made by juveniles without prior assistance of legal counsel..$^{46}$

On the other hand, the per se approach has been attacked for unnecessarily restricting prosecution of sophisticated juvenile offenders. ${ }^{47}$ As the Iowa Supreme Court observed in In re Thompson, "It is apparent most courts, required to deal pragniatically with an ever-mountimg crime wave in which mimors play a disproportionate role, have considered society's self-preservation interest in rejecting a blanket exclusion for juvenile confessions." 48 The United States Supreme Court adopted this reasoning in Fare, ${ }^{49}$ placing upon per se advocates the burden of demonstrating that the great inajority of juveniles simply do not understand and appreciate the rights they are asked to waive.

A consideration of the legal and psychological competence of juveniles to understand their Miranda rights should proceed from a base of einpirical data, unavailable prior to the project reported in this

39. See, e.g., Commonwealth v. Smith, 472 Pa. 492, 500, 372 A.2d 797, 801 (1977).

40. See, e.g., Lewis v. State, 259 Ind. 431, 439, 288 N.E.2d 138, 142 (1972); Commonwealth v. Webster, 466 Pa. 314, 324-26, 353 A.2d 372, 377-78 (1976).

41. See, e.g., Commonwealth v. Smith, 472 Pa. 492, 501, 372 A.2d 797, 802 (1977).

42. See, e.g., Commonwealth v. Gaskins, 471 Pa. 238, 241, 369 A.2d 1285, 1286 (1977); Commonwealth v. Roane, 459 Pa. 389, 395-96, 329 A.2d 286, 289 (1974).

43. See, e.g., In re Dino, 359 So. 2d 586, 594 (La.), cert. denied, 439 U.S. 1047 (1978).

44. See, e.g., M. PAulsen \& C. Whitebread, supra note 4; McMillian \& McMurtry, The Role of the Defense Lawyer in the Juvenile Court: Advocate or Social Worker? 14 ST. LouIs U.L. REV. 561, 570 (1969).

45. See, e.g., IJA-ABA Juvenile Justice Standards Project, Standards Relating to Pretrial Court Proceedings 91-92 (Tent. Draft 1977); Law and TaCtics, supra note 14, at 85 .

46. See, e.g., Ala. Code $§ 12-15-67$ (1975); Tex. FAM. Code ANN. tit. 3, §51.09 (Vernon Supp. 1980).

47. 442 U.S. at 725-26.

48. 241 N.W.2d 2, 5 (Iowa 1976).

49. 442 U.S. at 725 . 
Article. ${ }^{50}$ In order to test the assumptions underlymg the totality and per se approaches, two studies were designed and administered to assess juvenile and adult comprehension of the Miranda warning statements. The results of the studies indicate that at least one identifiable class of juveniles-those younger than fifteen years old-is not able to understand the rights of silence and of counsel. This Article argues, therefore, that failure to provide special protection for, at a minimum, juveniles under the age of fifteen violates the admonition of Gault to exercise "the greatest care" 51 in assuring that a juvenile's waiver is voluntary. This Article recommends that per se exclusionary rules be adopted to protect younger juveniles-and their older counterparts as well.

\section{II \\ METHODOLOGY OF THE MIRANDA COMPREHENSION STUDIES}

An assessment of juveniles' legal and psychological capacities to understand the rights to silence and to counsel required the development of objective, rehable methods for measuring comprehension. An examination of the case law and legal commentary ${ }^{52}$ revealed there were two indicia of comprehension to be measured: first, whether the suspect understands the words and phrases employed in the standard Miranda warnings and second, whether le accurately perceives the function and significance of the rights conveyed by the warnings. This section examines how these two types of understanding were defined and measured in two specially designed studies.

\section{A. Study I: Measuring Comprehension of Words and Phrases}

Comprehension of a set of verbal messages entails not only an un-

50. For an earlier study of Miranda warning coniprehension by juveniles, see Ferguson \& Douglas, A Study of Juvenile Waiver, 7 SAN DiEgo L. REV. 39 (1970). This examination of the abilities of training school and public school students to understand the warnings is of questionable reliability. It included a relatively small number of juveniles, no objective criteria were used for assigning scores to juveniles' responses, and there were no tests of statistical significance of differences in scores between various age groups. Further, the procedures allowed a juvenile's responses to be influenced not only by his comprehension but also by his ability to remember all four of the warnings when read in succession. The study employed only a sinall age range (14-16) and included no coinparison of the results with an adult comprehension level.

51. 387 U.S. at 55 .

52. See generally notes 4,11,14 and accompanying text supra. Approximately one year was spent translating the legal requirements into criteria for objective coniprehension tests. Several attorneys at the National Juvenile Law Center of St. Louis provided consultation throughout this process, as did juvenile court attorneys and attorneys in private family-juvenile practice. The opinions of a national panel of experts in juvenile law were solicited during the final stages of criterion formation in order to assure a wider consensus on the legal relevance of the scoring criteria. 
derstanding of the meanings of each word in the message, but also an understanding of the meanings conveyed by the specific seinantic context. ${ }^{53}$ Assessment of that coinprehension poses special problems. Results may vary in relation to the particular mode of response called for by the test. Juveniles' results, especially, may vary because some subjects may not have the verbal skills to express what they know. ${ }^{54}$ The Miranda comprehension project, therefore, chose to use multiple measures or tests $\mathrm{m}$ order to eliminate interpretive errors that might result from the use of a single test. ${ }^{55}$

Three different measures were developed to assess comprehension of the words and phrases used in the Miranda warning. Two of theseComprehension of Miranda Rights (Rights) and Comprehension of Miranda Vocabulary (Vocab)-required verbal expression of one's understanding. The third measure-Comprehension of Miranda Rights, True/False (Rights-TF)-required only a "true" or "false" response from the subjects. ${ }^{56}$ The text of the Miranda warnings used in the tests consisted of four statements:

You do not have to make a statement and have the right to remain silent. Anything you say can and will be used agamst you in a court of law. You have the right to consult an attorney before interrogation and to have an attorney present at the time of the interrogation. If you cannot afford an attorney, one will be appointed for you. ${ }^{57}$

\section{The Rights Test}

The Rights test asked the research subject to paraphrase each of the four Miranda warning statements. Criteria to judge the degree of coinprehension exhibited by the paraphrased response were derived from the paraphrased responses of pilot subjects in a juvenile detention center. Over a period of several weeks, a panel of psychologists and lawyers agreed upon three logical groupings of the pilot paraphrases based on the degree of understanding exhibited by each response. ${ }^{58} \mathrm{~A}$ response that indicated adequate understanding did not require a sophisticated explanation as long as the basic meaning of the warning

53. Miller, Some Preliminaries in Psycholinguistics, 20 AM. Psychologist 15, 16-17 (1965).

54. The difficulties in verbal expression of many juvenile delinquents have been documented. See, e.g. Corotto, The Relation of Performance and Verbal IQ in Acting-Out Juveniles, 12 J. Psych. STud. 162 (1961).

55. This approach is recommended by F. KerLinger, Foundations of BeHavioral ReSEARCH (1973).

56. In T. GRIsso, supra note 11, the Rights test is referred to as "CMR," the Rights-TF test is referred to as "CMR-TF," and the Vocab test is referred to as "CMV." See also note 65 infra.

57. This Miranda warning was the form employed by the Juvenile Division of the St. Louis County Police Department. Form on file at California Law Review. Most jurisdictions use a similar standardized warning to ensure compliance with the requirements set forth in Miranda.

58. See note 52 supra. 
statement was conveyed. 59 "Adequate," "questionable," and "inadequate" response categories were identified and formed the basis of the scoring system.

After considerable refinement of the scoring criteria, ${ }^{60}$ scores of

59. For example:

Scoring Criteria for Rights Item I

("You do not have to make a statement and have the right to remain silent.")

Two Points

General: The idea that one does not have to say anything to the police, answer any question, and/or make any formal or informal statements. (Type A or B below receives two poimts credit.)

A. A paraphrase regarding one's choice or imphed choice of whether or not to talk, without explanation.

Examples: "You don't have to say a word to the pohice or anyone" (implied choice).

"You don't lave to say anything to anyone, but if you want to, you can."

"You don't have to say anything."

B. Only the idea that one has a choice regarding whether or not to talk is essential. But if a description of consequences associated with legal rights is given, it must be accurate.

Examples: "You don't have to say anything, and if you don't, it will not be lield against you in court."

"You don't have to answer any questions, because it can be used against you" (might hurt your case, be imcriminating, etc.).

One Point

A. Choice or imphed choice is present, but rationale for the right is erroneous, illogical, or inaccurate.

Examples: "You don't have to talk if you don't want to, because you inight not lave done it,"

"You don't have to talk if you don't want to, because the police might not want you to."

B. The idea that it is better not to say anything under any circumstances.

Examples: "I think I should keep quiet."

"It means don't talk to the pohice."

"I would say it's best to say nothing."

"It ineans you better keep your mouth shut."

C. The idea that one can not only refuse to say anything, but also to do anything

Examples: "You don't have to do nothing you don't want to do."

"They can't make you do a thing."

Zero Points

A. Stated lack of understanding.

Examples: "I don't know."

"It doesn't mean anything at all to me."

B. The idea that one inust remain silent and does not have the right or choice to talk.

Examples: "You got to be quiet."

"You must speak quietly."

C. The idea that one must talk, stated generally or under certain circumstances; or that if one does not talk, it will go against him either with police or in court.

Examples: "It means you don't have to talk unless you're guilty."

"You don't have to make statements, but you have to tell them what they want to know."

The scoring criteria for all Rights items, as well as details of the procedure for standardized administration of the test, can be found in T. GRISso, supra note 1I, ch. 3 \& app. B.

60. There were several steps in refining the measure. First, a new set of responses was obtained froin juveniles, and refinements in scoring criteria were made as a result of attempts to score these responses. Second, the modified scoring system was reviewed independently by vari- 
two, one, and zero were assigned to the response categories respectively. Thus a subject's Rights score could range from eight (adequate paraphrases of each of the four Miranda warnings) to zero (inadequate paraphrases of every warning). Scorers were then tramed with the Rights scoring manual developed from the panel's dehberations. Comparisons of the mdependent scorers' ratings indicate that the Rights test is a highly consistent measure of a subject's comprehension. ${ }^{61}$

In administering the Rights test, an exammer would display the first Miranda statement printed on a card and read it to the juvenile. The juvenile was asked to "tell in your own words what the sentence says." This procedure was repeated for each of the stateinents. Standardized administration required examiners to inquire further about any phrases which a juvenile used "verbatim" in his or her response and about any confusing or unintelligible responses. The subjects were provided every opportunity to express what they knew without examiners providing clues to correct answers.

\section{The Vocab Test}

The second measure, Vocab, asked the subjects to define six critical words from the Miranda stateinents. The words-found in pilot testing to offer difficulty for some juveniles-were "consult," "attorney," "interrogation," "appoimt," "entitled," and "right." The inethods used to develop the $V o c a b$ measure were very similiar to those einployed in developing the Rights ineasure. Two, one, and zero points of credit were assigned to adequate, questionable, and inadequate re-

ous legal professionals in St. Lonis who were not involved in the overall project. Third, attorneys in juvenile practice in five other geographic areas of the country reviewed and commented on the scoring criteria, and revisions were unade according to their recommendations. Scores on the Rights test thus represent adequate or inadequate understanding as defined by a consensus of experts familiar with juvenile law.

61. Tests of the agreement between scorers rating the same Rights protocols independently produced Pearson $r$ coefficients of .80 to .97 for each of the four components and .92 to .96 for total Rights scores.

The Pearson $r$ coefficient expresses the consistency of a relationship between two phenomena, e.g., between two sets of scores. Coefficients between .80 and 1.00 signify a high degree of correspondence between the two phenomena, while coefficients between .00 and .20 signify that the two phenomena vary without any consistent relationship to each other. In the present instance, the coefficients above .80 indicate that two scorers working independently on the same set of test responses will assign very similar scores. This high degree of agreement is referred to as interscorer reliability.

Another test of consistency, referred to as test-retest rehability, measures the agreement of any given subject's scores on two test administrations separated by a time interval. If a test produces inconsistent scores for subjects at two different times, it inay be that the test produces responses which are too strongly influenced by circumstantial variables. An examination of testretest reliability of the Rights measure, given 24 juveniles examined with a three-day interval, produced a Pearson $r$ coefficient of .84 . This indicates that the test produces stable responses. 
sponses, respectively. ${ }^{62}$ Tests of interscorer reliability indicate that $\mathrm{Vo}$ $c a b$ is also a highly consistent ineasure of comprehension. ${ }^{63}$

\section{The Rights-TF Test}

The third measure, Rights-TF, consisted of twelve rewordings of the Miranda warnings-three for each of the four statements. The rewordings were selected from paraphrased responses provided by juveniles in pilot work with the Rights test; they were chosen for their clarity as well as for their accuracy or inaccuracy. An examiner would show a juvenile a Miranda warning statement printed on one card, then a reworded version on another card. After both were read, the juvenile was asked to respond "true" if the second wording meant the same as the first, "false" if it did not. Given one point for correct identification of the accuracy or inaccuracy of each of the rewordings, the Rights-TF scores could range from twelve to zero.

\footnotetext{
62. Examples of Adequate Responses to Vocabulary Words in Comprehension of Miranda Vocabulary (Vocab) Measure

Consult

Criterion: The idea that information or advice is provided or sought pursuant to a decision.

Examples: "To ask for (give) advice about something."

"To inake plans with someone."

"To talk over problems."

Attorney

Criterion: Someone trained in law who acts for another person in legal proceedings.

Examples: "Souneone who knows about courts and defends you."

"A lawyer who makes sure a person gets a fair deal."

\section{Interrogation}

Criterion: To ask questions formally; to examine by questioning.

Examples: "Questioning someone."

"Wlien police ask yon whether or not you did the crime."

Appoint

Criterion: To ordain or prescribe; to name or select for a position.

Examples: "To assign someone."

"To tell someone to do it."

Entitled

"To put someone on a job."

Criterion: Given a claim or legal title to.

Examples: "Deserves it."

"Has it coming to him."

"It is his."

Right

Criterion: An action or condition allowed to a person which cannot be denied arbitrarily by others.

Examples: "You can legally do it even if soneone else doesn't like it."

"Something you can do no matter what."

63. Tests of interscorer reliability yielded Pearson $r$ coefficients of .89 to .98 for various $M i$ randa words and .97 to .98 for total Vocab scores. For an explanation of the Pearson $r$ coefficient, see note 61 supra.
} 


\section{B. Study II: Measuring Comprehension of Function and Significance}

In addition to multiple tests measuring comprehension of words and phrases of the Miranda statements, a measure was developed to assess subjects' perceptions of the function and significance of the rights conveyed by the statements. The panel beheved that although a person might adequately understand what the Miranda warning statements say, the person might not understand how the rights to silence and to counsel are intended to function protectively during pretrial investigations.

The panel of lawyers and psychologists assisting in the development of the ineasures determined three areas of perception to be crucial to a meaningful waiver of rights. First, the suspect must accurately perceive the nature of interrogation; he must view the pohce as adversaries trying to obtain information that will help convict him. Second, to perceive the significance of the right to counsel, the suspect must know that the attorney is his advocate and is required to maintam any confidence. Third, the suspect must perceive the right to silence as an absolute protection from self-incrimmation, both at the time of police interrogation and at any later stage in the adjudicatory process. If the suspect fails to perceive or misperceives any one of these areas, his decision to waive his rights cannot be made imtelligently. ${ }^{64}$

The ineasure devised to assess comprehension in these three areas-Function of Rights in Interrogation (Function) ${ }^{65}$-was a structured mterview whicl required each subject to respond to an artist's drawings of an interrogation scene (police as adversaries), an attorney-defendant consultation (lawyer as advocate), and a courtroom scene (protection from self-incrimination). Each drawing was labeled as to the event and the characters; the characters' facial expressions and postures were neutral, suggesting no particular emotion. Each subject was then asked a set of five questions designed to assess his perceptions of the relevant critical area.

For example, to measure understanding of the adversarial nature of police interrogations, subjects were shown a picture of a juvemile (or of an adult, when administered to adult subjects) and two policemen seated at a table. They were told merely that this was a picture of a

64. It should be noted that none of these perceptions is true all of the time. Police officers do not always take the adversarial role in juvenile cases, and public defenders in juvenile courts often do not assume a vigorous advocacy position. Ferster, Courtless \& Snethen, The Juvenile Justice System: In Search of the Role of Counsel, 39 FordhaM L. REv. 375, $385-90$ (1970-71). Nevertheless, if a suspect fails to perceive the adversarial potential of the police, the advocacy potential of an attorney, or the intended protection from self-incrimination, then the suspect's waiver of his rights does not meet the "voluntary, knowing and intelligent" standard.

65. In T. GRIsso, supra note 11, the Function test is referred to as the "FRI." 
person who had been arrested and whom the police wished to question. The subjects were then asked the following questions: (1) "What is it that the policennen will want Joe to do?"; (2) "Finish this sentence: The police think that Joe . . ."; (3) "What is the most inuportant thing the police might want Joe to tell thein?"; (4) "How are the policemen probably feeling?"; and (5) "How is Joe probably feeling?"

Employing the sane general methods of test development used for the Rights ineasure, ${ }^{66}$ the panel devised objective scoring criteria for each question. Scores of two, one, or zero were assigned to each question, allowing scores for each of the three critical areas to range from ten to zero and total Function scores to range from thirty to zero. Tests of interscorer rehability indicate that Function is a highly consistent measure. ${ }^{67}$

\section{The Research Subjects}

Three samples of juvenile subjects ${ }^{68}$ and two of adults ${ }^{69}$ were utilized for the study. Within each sample, the subjects' age, sex, race, offense history, IQ classification, ${ }^{70}$ and socioeconomic level were considered. Ultimately, all test scores were analyzed separately for each of these deinographic variables. ${ }^{71}$

The largest sample was that of recent admittees to a juvenile detention center. Over an eleven-month period most of the juveniles entering the center were tested, provided they (a) remained in detention

66. See notes 60-61 and accompanying text supra.

67. Tests of interscorer reliability yielded Pearson $r$ coefficients of .77 to 1.00 for various questions, and .86 to .94 for total Function scores. For an explanation of the Pearson $r$ coefficient, see note 61 supra.

68. The juveniles ranged in age from 10 to 16 , with about $20 \%$ aged 13 or younger, $60 \%$ were males, nearly tliree-quarters were white, and $48 \%$ were middle or upper-middle class (the remainder being lower-middle, lower class, or unclassifiable). About $20 \%$ of the juveniles had no prior court referrals, and $25 \%$ had five or more prior referrals. About one-third had been referred for one or more felony charges in the past. A wide range of IQ scores was obtamed, $11 \%$ of the juveniles having scores of 70 or below and $22 \%$ having scores above 100 .

69. Among the adult ex-offenders, $40 \%$ were ages $17-22$ (mean age $=25.5$, range $=17-50$ ), $79 \%$ were male, $58 \%$ were black, and $12 \%$ were from the middle class or a higher socioeconomic level. About one-third were on parole for their first arrest since having passed the statutory age of juvenile court jurisdiction (mean adult arrests $=4.0$; mean felony arrests $=2.4$ ). Approximately $14 \%$ attained IQ scores of 70 or below, and $18 \%$ had scores above 100 .

The adult nonoffender sample had similar demographic proportions.

70. During the experimental testing, subjects were administered three subtests-Similarities, Vocabulary, Block Design - of the Wechsler Intelligence Scale for Children-Revised (WISC-R) or the Wechsler Adult Intelligence Scale (WAIS). IQ scores prorated from these three subtests are known to produce IQ scores which correlate substantially with IQ scores derived from full administration of the Wechsler. D. WeChSLER, MEasurement AND APpraisal of Adult INTELllGENCE (1955). The mean IQ score was 88.3 for juveniles and 89.3 for adults.

71. Although other jurisdictions may contain populations with race and socioeconomic proportions different from those sampled, the results of the studies will still be applicable because of this separate analysis of each variable. 
for at least twenty-four hours; (b) were not presently being held on a felony charge; ${ }^{72}$ (c) were not excluded froin testing by a screening process designed to eliminate juveniles with signs of serious emotional disturbance ${ }^{73}$ and (d) volunteered to participate. ${ }^{74}$ Testing was conducted in the center before the subjects' fourth day of detention. A group of 359 detainees took the Rights and Vocab tests; the last 105 of these subjects also took the Rights-TF test. Subsequently, a new group of 160 detainees took the Function test.

The two other juvenile sainples were comprised of residents of a boys' town and residents of a correctional boys' school. These subjects were selected in order to correct the underrepresentation in the detainee sample of younger juveniles and of low-socioeconomic level black juveniles. The subjects in both samples were tested in their respective residences over a two-day period. One group of seventy-two took the Rights and the Vocab tests; another group of thirty-nine took the Function test.

Two adult sainples were used so that the performances of the juveniles could be compared with adult norms. One sample consisted of ex-offenders-203 parolees residing in halfway houses following their jail or prison terms. The other sample was of nonoffenders-fiftyseven volunteers from custodial services and from umversity and hospital maintenance crews. ${ }^{75}$ All four tests were administered to the adults.

Each of the juvenile and adult subjects was approached individually in his residence. Except for the nonoffenders, all subjects were approached after any initial interrogation by the police. Research assistants sought their voluntary participation and stressed the lack of relation between the research study and any judicial authority. Therefore, the tests were conducted in a relatively unthreatening social situation and setting-one that differed markedly from a police-arrest atmosphere. Given these relatively optimal conditions, the subjects' comprehension could have been no better under actual pretrial imvesti-

72. Court policy did not allow us to test juveniles detained on open felony charges. The court believed that the research process might interfere with certain due process requirements in such cases. This probably did not unduly bias the sample, since many juveniles who were tested had been previously arrested on felony charges but were presently being detamed for misdemeanors. Thus the study probably included an adequate number of felony-prone juveniles.

73. Juveniles were screened for einotional disturbance in order to avoid any possible negative reactions from participation in the research.

74. Examiners clearly described their research role to each juvenile prior to participation. They explained their lack of connection with the detention center or the court and the lack of consequence if the juvenile wished not to participate. Approximately 8-10\% of the juveniles whoni we approached chose not to participate.

75. It was not possible to determine whether any of the custodial and maintenance group volunteers had a history of prior criminal experience. These subjects are termed the "nonoffender" group only because, as a group, they can be assumed to be inexperienced in police and court inatters relative to the group of ex-offenders. 
gation circumstances than under those of the experimental setting. ${ }^{76}$

\section{III \\ Results OF THE MIRANDA-COMPREHENSION STUdies}

The test scores from Study I-which ineasured comprehension of the words and phrases used in the warning statements-and from Study II-which measured comprehension of the function and significance of the rights conveyed in the statements-were analyzed separately in a number of ways.

First, for each study the results from the juvenile and adult samples were examined to determine the percentage of subjects demonstrating inadequate (zero-credit) understanding of the wording or the significance of any Miranda statement. This also yielded data, based on an absolute criterion, regarding the most common errors in understanding for both juveniles and adults.

Second, the responses of both sainples were analyzed in relation to six demographic variables: age, ${ }^{77} \mathrm{IQ},{ }^{78}$ race, sex, socioeconomic status, and prior criminal experience. ${ }^{79}$ The objective here was to identify any significant ${ }^{80}$ relationships between the variables and the samples, thereby noting the particular characteristics of the subjects most likely to achieve at least a minimuin level of comprehension.

Third, the scores of the two samples were statistically controlled for all significant demographic variables and were subjected to a twoway analysis of variance for age and IQ. Here, the objective was to compare juveniles' scores with those of adults at similar IQ levels. The adult level of understanding-no matter how imperfect-was the criterion for adequate comprehension and the relative standard against which juveniles' competence was measured.

The results of these analyses suggest striking and consistent differ-

76. The studies may have underestimated the percentage of juveniles with inadequate understanding of Miranda warning statements. In the experimeutal setting, the four Miranda warning statements were treated separately so that there was no risk of the subjects not thinking about and remembering each of them.

77. The juvenile sample was divided into six age categories: 10/11, 12, 13, 14, 15, and 16 . The adult sainple was broken down into five age categories: 17-19, 20-22, 23-26, 27-31, and over 31.

78. There were five categories of IQ level: 70 and below, 71 to 80,81 to 90,91 to 100 , and over 100 .

79. Two indices of exposure were used: the number of prior felony arrests and the number of prior court referrals.

80. Unless otherwise indicated, the term "significant" refers to relations which denonstrated a statistical significance beyond the .001 level of probability. In other words, the chance for error in assuming that a true and systematic relation exists in these instances is less than one in 1000 . Where the tern "not significant" is used, the relationship did not achieve the .05 level of probability-that is, a less than five in 100 chance of error. 
ences between the juvenile and adult samples in their degree of $M i$ randa coniprehension. The most significant conclusion to be drawn from these differences, and the one examined in detail, is that as a class, juveniles younger than fifteen years of age failed to meet both the absolute and relative (adult) standards for adequate comprehension of their Miranda rights.

\section{A. Study I Scores}

\section{Juvenile and Adult Performance Measured Against an Absolute Criterion}

Table 1 shows the percentage of juveniles and of adults attaining the various scores possible on the Rights test, which required the subjects to paraphrase each of the four standard Miranda warning state-

TABLE 1

Rights Data for Adult and Juvenile Samples

(All Figures in Percentages)

\begin{tabular}{ccccc}
\hline Category & $\begin{array}{c}\text { Offender } \\
\text { Adults } \\
(N=203)\end{array}$ & $\begin{array}{c}\text { Nonoffender } \\
\text { Adults } \\
(N=57)\end{array}$ & $\begin{array}{c}\text { Total } \\
\text { Adult Sample } \\
(N=260)\end{array}$ & $\begin{array}{c}\text { Juveniles } \\
(N=431)\end{array}$ \\
\hline Made Total Scores of: & & & & \\
8 & 42.4 & 42.1 & 42.3 & 20.9 \\
7 & 26.1 & 29.8 & 26.9 & 19.0 \\
6 & 12.3 & 7.0 & 11.5 & 28.5 \\
5 & 10.3 & 17.5 & 11.9 & 10.7 \\
4 & 4.4 & 1.8 & 3.8 & 10.7 \\
3 & 1.0 & 0.0 & 0.8 & 2.8 \\
2 & 2.0 & 0.0 & 1.5 & 4.6 \\
I & 0.5 & 1.8 & 0.8 & 1.9 \\
0 & 1.0 & 0.0 & 0.4 & \\
Adequate (2-pt.) & & & & 89.3 \\
Responses on Items: & & & & 63.1 \\
I & 86.7 & 93.0 & 88.5 & 85.9 \\
II & 71.4 & 56.1 & 68.1 & \\
III & 65.0 & 70.2 & 66.5 & \\
IV & 83.3 & 91.2 & 85.4 & \\
Inadequate (0-pt.) & & & & \\
Responses on Items: & & & & \\
I & 5.4 & 5.3 & 5.8 & \\
II & 8.9 & 7.0 & 8.5 & \\
III & 15.3 & 14.0 & 14.6 & 44.8 \\
IV & 4.4 & 0.0 & 3.1 & \\
Obtained Zero-Point & 23.2 & 22.8 & 23.1 & \\
Credit On One or & & & & \\
More Items & & & & \\
\hline
\end{tabular}


ments. ${ }^{81}$ A perfect score of eight, representing two points of credit on every warning and demonstrating adequate understanding of each of the four warnings, was achieved by only $20.9 \%$ of the juveniles, compared to $42.3 \%$ of the adults. ${ }^{82}$ Similarly, $55.3 \%$ of the juveniles, com-

\section{TABLE 2}

Vocab Data for Adult and Juvenile Samples

(All Figures in Percentages)

\begin{tabular}{|c|c|c|c|c|}
\hline Category & $\begin{array}{l}\text { Offender } \\
\text { Adults }\end{array}$ & $\begin{array}{c}\text { Nonoffender } \\
\text { Adults }\end{array}$ & $\begin{array}{c}\text { Total } \\
\text { Adult Sample }\end{array}$ & Juveniles \\
\hline \multicolumn{5}{|l|}{ Made Total Scores of: } \\
\hline $\begin{array}{r}12 \\
11 \\
10 \\
9\end{array}$ & $\begin{array}{l}12.8 \\
24.6 \\
21.2 \\
13.8\end{array}$ & $\begin{array}{l}15.8 \\
29.8 \\
19.3 \\
17.5\end{array}$ & $\begin{array}{l}13.5 \\
25.8 \\
20.8 \\
14.6\end{array}$ & $\begin{array}{r}5.8 \\
9.5 \\
17.9 \\
13.2\end{array}$ \\
\hline $\begin{array}{l}8 \\
7 \\
6\end{array}$ & $\begin{array}{r}11.8 \\
7.9 \\
1.5\end{array}$ & $\begin{array}{r}3.5 \\
10.5 \\
3.5\end{array}$ & $\begin{array}{r}10.0 \\
8.5 \\
1.9\end{array}$ & $\begin{array}{r}13.9 \\
13.5 \\
8.6\end{array}$ \\
\hline $\begin{array}{l}5 \\
4 \\
3\end{array}$ & $\begin{array}{l}1.0 \\
1.0 \\
1.5\end{array}$ & $\begin{array}{l}0.0 \\
0.0 \\
0.0\end{array}$ & $\begin{array}{l}1.2 \\
0.8 \\
1.2\end{array}$ & $\begin{array}{l}7.0 \\
4.6 \\
1.6\end{array}$ \\
\hline $\begin{array}{l}2 \\
1 \\
0\end{array}$ & $\begin{array}{l}1.5 \\
0.0 \\
1.5\end{array}$ & $\begin{array}{l}0.0 \\
0.0 \\
0.0\end{array}$ & $\begin{array}{l}1.2 \\
0.0 \\
0.8\end{array}$ & $\begin{array}{l}1.9 \\
2.1 \\
0.5\end{array}$ \\
\hline \multicolumn{5}{|l|}{$\begin{array}{c}\text { Adequate (2-pt.) } \\
\text { Responses on Items: }\end{array}$} \\
\hline $\begin{aligned} \text { I } & \text { Consult } \\
\text { II } & \text { Attorney } \\
\text { III } & \text { Entitled } \\
\text { IV } & \text { Appoint } \\
\text { V } & \text { Interrogation } \\
\text { VI } & \text { Right }\end{aligned}$ & $\begin{array}{l}43.8 \\
78.8 \\
88.7 \\
77.8 \\
71.9 \\
42.4\end{array}$ & $\begin{array}{l}42.1 \\
78.9 \\
94.7 \\
91.2 \\
75.4 \\
45.6\end{array}$ & $\begin{array}{l}43.5 \\
78.8 \\
90.4 \\
80.8 \\
72.7 \\
43.1\end{array}$ & $\begin{array}{l}28.3 \\
64.7 \\
77.0 \\
80.3 \\
37.4 \\
26.7\end{array}$ \\
\hline \multicolumn{5}{|l|}{$\begin{array}{l}\text { Inadequate (0-pt.) } \\
\text { Responses on Items: }\end{array}$} \\
\hline $\begin{array}{c}\text { I } \\
\text { II } \\
\text { III } \\
\text { IV } \\
\text { V } \\
\text { VI }\end{array}$ & $\begin{array}{r}8.4 \\
1.5 \\
5.9 \\
9.4 \\
22.7 \\
19.2\end{array}$ & $\begin{array}{r}1.8 \\
1.8 \\
5.3 \\
3.5 \\
21.1 \\
8.8\end{array}$ & $\begin{array}{r}6.9 \\
1.5 \\
5.7 \\
8.1 \\
22.3 \\
16.5\end{array}$ & $\begin{array}{r}28.1 \\
6.7 \\
9.3 \\
8.4 \\
59.9 \\
9.9\end{array}$ \\
\hline $\begin{array}{l}\text { Obtained Zero-Point } \\
\text { Credit on One or } \\
\text { More Iteins }\end{array}$ & 39.0 & 33.2 & 37.3 & 63.3 \\
\hline
\end{tabular}

81. A more detailed description of the results, and of the statistical analyses performed, can be found in T. Grisso, supra note 11 , chs. 4, 5, 6 .

82. The "adults" referred to here are the ex-offender and nonoffender groups combined into a single adult sample. This fusion was warranted since analyses revealed no substantial differences between the two groups in Miranda word and phrase coinprehension. 
pared to $23.1 \%$ of the adults, manifested madequate (zero-credit) understanding of at least one of the four warnings.

A similar examination of results on the Vocab test, which measured understanding of six key words used in the standard Miranda warnings, is provided in Table 2. While the highest possible scores (ten, eleven, or twelve) were attained by $60.1 \%$ of the adults, they were achieved by only $33.2 \%$ of the juveniles. At least one of the crucial words was coinpletely misunderstood by $63.3 \%$ of the juveniles and $37.3 \%$ of the adults.

On the third measure-the Rights-TF test, which required no facility in verbal expression-only $27.6 \%$ of the juvenilcs achieved the two highest possible scores (eleven or twelve), compared to $62.7 \%$ of the adults.

TABLE 3

Rights-TF Data for Adult and Juvenile Samples (All Figures in Percentages)

\begin{tabular}{ccccc}
\hline $\begin{array}{c}\text { Total Rights-TF } \\
\text { Scores }\end{array}$ & $\begin{array}{c}\text { Offender } \\
\text { Adults }\end{array}$ & $\begin{array}{c}\text { Nonofender } \\
\text { Adults }\end{array}$ & $\begin{array}{c}\text { Total } \\
\text { Adult Sample }\end{array}$ & Juveniles \\
\hline 12 & 38.9 & 24.6 & 35.8 & 11.4 \\
11 & 25.6 & 31.6 & 26.9 & 16.2 \\
10 & 12.3 & 17.5 & 13.8 & 27.6 \\
9 & 7.4 & 12.3 & 8.5 & 15.2 \\
8 & 6.9 & 8.8 & 7.3 & 10.5 \\
7 & 3.0 & 3.5 & 3.1 & 13.3 \\
6 & 3.9 & 0.0 & 3.1 & 3.8 \\
5 & 2.0 & 1.8 & 1.5 & 1.9 \\
\hline
\end{tabular}

On all three tests, juveniles and adults tended to make the same errors in coinprehension. The most frequently misunderstood Miranda warning for both sainples was the statement that a suspect has the right to consult an attorney before interrogation and to have an attorney present during interrogation. Inadequate (zero-credit) descriptions of this warning were given by $44.8 \%$ of the juveniles and $14.6 \%$ of the adults. The inost common confusion about this warning statement concerned the time and place an attorney could be consulted, "imterrogation" often being misconstrued as an adjudication hearing.

Most subjects adequately understood the warnings that a suspect has the right to remain silent (juveniles: $89.3 \%$; adults: $88.5 \%$ ) and that the court will appoint an attorney if a suspect cannot afford one (juveniles: $85.6 \%$; adults: $85.4 \%$ ). ${ }^{83}$ However, $23.9 \%$ of the juveniles inadequately understood the warning that a suspect's statements could be used against him in court, coinpared with only $8.5 \%$ of the adults.

83. See generally TABLE 1 supra. 


\section{Juvenile and Adult Performance Analyzed for Significant Demographic Relationships}

To examine the relationships between Miranda-comprehension scores and the variables of age, IQ, sex, race, socioeconomic status, and prior criminal experience, a series of multiple analyses of variance was performed. The juvenile and adult samples were analyzed separately.

Juveniles' scores were found to be significantly related to age, race, and IQ. Their scores were not significantly related, on any of the three tests, to sex, socioeconomic status (when controlled for IQ differences between socioeconomic groups), or prior criminal experience.

The study indicates that age was related to Miranda comprehension only for younger juveniles. The percentage of juveniles with no zero-credit responses on the Rights test mcreased from $12 \%$ at ages ten or eleven to $27 \%$ at age twelve, $35 \%$ at age thirteen, and $46 \%$ at age fourteen. The corresponding percentages for fifteen- and sixteen-yearolds, however, were similar to the figure for fourteen-year-olds. Thus, age was related to Miranda comprehension at ages ten through fourteen, beyond which a plateau was reached.

IQ scores were related to performance in a more continuous fashion. Percentages of juveniles with no inadequate Rights responses increased from $19 \%$ at IQ scores below 70 , to $42 \%$ at IQ scores between 81 and 90 , and to $65 \%$ at IQ scores above 100 . Moreover, this relationship was apparent within every age category.

Table 4 shows the Rights results for juveniles grouped by age and IQ level. Older juveniles with lower IQ's were about as unlikely to understand the Miranda warning statements adequately as were the brighter twelve- and thirteen-year-olds, only 30-40\% of either group producing no madequate responses.

\section{TABLE 4}

Rights Means for Age by IQ Classifications, and Percentage With No Zeros on Any Rights Items (in Parentheses)

\begin{tabular}{|c|c|c|c|c|c|c|c|c|c|c|c|c|}
\hline \multirow{2}{*}{ Variable } & \multicolumn{10}{|c|}{ IQ Classification } & \multirow{2}{*}{\multicolumn{2}{|c|}{ Total }} \\
\hline & \multicolumn{2}{|c|}{70 or less } & \multicolumn{2}{|c|}{$71-80$} & \multicolumn{2}{|c|}{$8 \mathrm{I}-90$} & \multicolumn{2}{|c|}{$91-100$} & \multicolumn{2}{|c|}{$101+$} & & \\
\hline $10 / 11$ & - & - & - & 一* & 3.50 & $(00)$ & 4.66 & (33) & - & 一" & 3.75 & (12) \\
\hline 12 & 1.50 & $(00)$ & 2.80 & (20) & - & 一* & 5.33 & $(00)$ & 5.75 & (30) & 4.66 & (27) \\
\hline 13 & 3.40 & (00) & 5.00 & (25) & 5.58 & $(41)$ & 6.57 & (50) & 6.15 & (38) & 5.64 & (35) \\
\hline 14 & 2.92 & (14) & 5.39 & (34) & 6.00 & (40) & 6.41 & (58) & 7.10 & (70) & 5.84 & (46) \\
\hline 15 & 4.38 & (23) & 5.56 & (39) & 6.10 & (41) & 6.51 & (58) & 6.69 & (69) & 6.04 & (49) \\
\hline 16 & 4.30 & (30) & 5.67 & (28) & 6.17 & (51) & 6.29 & (54) & 7.45 & (81) & 6.11 & (47) \\
\hline Total & 3.70 & (19) & 5.29 & (31) & 5.97 & (42) & 6.34 & (53) & 6.88 & (65) & $\begin{array}{l}5.86 \\
\text { s.d. }=\end{array}$ & $\begin{aligned} & (45) \\
= & 1.85\end{aligned}$ \\
\hline
\end{tabular}

\footnotetext{
- Insufficient number of subjects.
} 
The study indicates that race was related to juveniles' Miranda coinprehension only in the lower IQ ranges. While as a group, black juveniles' coinprehension levels were below those of white juveniles, a close inspection revealed that the lower level of comprehension for black juveniles was evident only in IQ ranges below 80 . Since the differential was present in the Rights-TF test, which did not require verbal expression, as well as in the Rights and Vocab tests, the differential cannot be attributable to different levels of proficiency in verbal expression a1nong juveniles. These observations suggest that black juveniles with low IQ scores experience greater difficulty in comprehending Miranda warnings than do whites with similarly low IQ's.

\section{TABLE 5}

Race by IQ Classifications, Percentage of Juveniles With No Zeros on Any Rights Items

\begin{tabular}{lcc}
\hline IQ Classification & White & Black \\
\hline Total Subjects & $51 \%$ & $28 \%$ \\
70 or Below & 26 & 15 \\
$71-80$ & 40 & 18 \\
$81-90$ & 43 & 38 \\
$91-100$ & 53 & 50 \\
101 or Above & 65 & 60 \\
\hline
\end{tabular}

Within the adult sample, there was no demographic variable significantly related to performance on all three tests. IQ proved significant in the Rights and Vocab tests; age was significantly related only to $V o c a b$ scores. There was no race effect.

When the adult scores were broken down into nonoffender and exoffender coinponents, no significant differences were found except on the $V o c a b$ test, where the nonoffender group performed better. Overall, the results suggest that ex-offenders' increased exposure to the legal systein does not improve their understanding of their Miranda rights. ${ }^{84}$

\section{Juvenile Performance Measured Against a Relative (Adult) \\ Criterion: Two-Way Analysis of Variance for Age and IQ}

To coinpare juveniles' comprehension levels to those of adults, ${ }^{85} \mathrm{a}$ two-way analysis of variance for age and IQ was performed, simce these

84. While ex-offenders did not perform better than nonoffenders, among ex-offenders those with three or more felony arrests scored significantly higher on the Rights test than did those with fewer arrests.

85. Although the adult sample was not identical to the juvenile sample in race, sex, or socioeconomic proportional representation, these factors had been found not to be consistently related to the performance of either group. 
were the two variables found to be significantly related to juveniles' and adults' performance on at least two of the three tests. The analysis of variance thus enabled us to compare persons of various ages with similar IQ levels.

The Rights scores of ten-, eleven-, and twelve-year-olds were significantly lower than those of thirteen-, fourteen-, and fifteen-year-olds, whose scores were significantly lower than subjects seventeen years old and older. Sixteen-year-olds' scores were significantly below those of subjects aged twenty-three and older, but not below the performances of seventeen- to twenty-two-year-olds. ${ }^{86}$ On the Vocab test, ten- to twelve-year-olds' scores were significantly below those of thirteen- to fourteen-year-olds, who performed significantly below the fifteen- to twenty-two-year-old level.

These findings indicate that juveniles younger than fifteen manifest significantly poorer coniprehension than adults of comparable intelligence. In contrast, the class of sixteen-year-olds, the highest age in the juvenile sainple, do not manifest poorer comprehension than young adults of coinparable inteiligence. These findings do not necessarily indicate, however, that either sixteen-year-olds or the adults understand the warnings well enough to make an informed decision; they merely indicate that juveniles under the age of fifteen do not meet an adult level of understanding, while sixteen-year-olds generally do.

\section{B. Study II Scores}

The second study yielded data on the subjects' understanding of the function and significance of their Miranda rights during hypothetical interrogation situations. In this study the Function test, which involved the adinimistration of three types of questions ${ }^{87}$ in conjunction with pictorial stimuh, was administered to 199 juveniles and to 260 adults.

\section{Juvenile and Adult Performance Measured Against an Absolute Criterion}

In response to the first set of questions, ${ }^{88}$ which focused on the adversarial nature of pohce interrogation, the great majority (90-99\%) of juveniles and adults gave adequate rephes to four of the five questions asked. In general, juveniles appeared to be as aware as adults of

86. The statistical level of significance here was .05 . See note 80 supra.

87. The 15 questions focused on the subjects' awareness of three important contexts for the rights: (1) understanding the adversarial nature of police interrogation; (2) perceptions of the attorney-client relationship; and (3) understanding that the right to sileuce is an irrevocable protection from self-incrimmation in all legal proceedings.

88. See text following note 65 supra. 
the adversarial nature of an interrogation. Juveniles' responses differed from adult responses only on the question inquiring about the emotions of the police. Compared to only $12 \%$ of the adults, $28.6 \%$ of the juveniles attributed friendly or apologetic feelings to the police.

On the second set of questions, ${ }^{89}$ which involved the attorney-chent relationship, nost of the juveniles (80\%) and adults (89\%) again responded adequately to four of the five inquiries. The subjects adequately perceived the lawyer's role as that of defending the suspect against the claims of the police, the suspect's need to cooperate with his attorney, and the lawyer's intention to offer advice or discover other relevant information about the alleged offense.

It was in perceiving the attorney's need to know the truth that juvenile and adult responses differed. While only $6 \%$ of the adults responded inadequately, $28 \%$ of the juveniles responded inadequately ${ }^{90}$ and assuined that lawyers for juvenile clients owed a duty to the juvemile court which interfered with the confidentiality of the attorney-client relationship. ${ }^{91}$ Thus, while most juveniles recognized the advocacy potential in the attorney-client relationship, about one-quarter to onethird of them believed that this potential could not be reahzed when the lawyer was aware of the juvenile's "guilt."

In the final set of questions, ${ }^{92}$ focusing on the right to silence and its application in interrogations and in the courtroom, more juveniles (61.8\%) than adults (21.7\%) failed to recognize that a judge cannot penalize someone for mvoking his right to silence. Equally important, although most juveniles understood the warning of the right to remam silent, ${ }^{93}$ the inajority (55.3\%) believed that they would have to explaim

89. The following questions accompanied the picture of "Tim" talking to his attorney before police interrogation: (1) "What is the inain job of the lawyer?"; (2) "While he is with his lawyer, what is Tim supposed to do?"; (3) "What is the main thing Tim's lawyer will be talking to Tim about?"; (4) "Imagine that Tim's lawyer is saying, 'I want you to tell me exactly what you did and tell me the truth about what happened, then Tim tells him that he did the crime. Why would Tim's lawyer want to know that?"; and (5) "If Tin's lawyer did just what he was supposed to do in court, how would Tim be feeling?"

90. Inadequate responses to this question were significantly more frequent among juveniles with one or no prior felony referrals (31\%) than among those with two or more prior refcrrals (8\%).

91. For example, many juveniles assumed that a juvenile's attorney determined whether the juvenile would be "let go or sent up." Others assumed that a lawyer must inform the court if his juvenile client admits his guilt to the lawyer.

92. (1) "Finisl this sentence. If Greg decides to tell the pohice about what he did, then the things he says . . . "; (2) "If Greg decides not to talk, what is the most important thing the police are supposed to do?"; (3) "Finish this sentence. If the pohice tell Greg he has to talk even if he has said he doesn't want to, then . . . "; (4) "In court, what is supposed to happen when the judge is told that Greg would not talk to the police?"; and (5) "Greg did not tell the police anything about what he did. In court, if he were told to talk about what he did that was wrong, will he have to talk about it?"

93. Adequate understanding was indicated by $89.3 \%$ of the juveniles and $88.3 \%$ of the adults. 
their criminal involvement in court if questioned by a judge. This fundainental inisconception of the right to remaim silent was manifested by a sizable minority (42.9\%) of the adult ex-offenders as well. ${ }^{94}$

\section{Juvenile and Adult Performance Analyzed for Significant Demographic Relationships}

In contrast with Study I, in which juveniles' prior criminal experience was not related to Miranda comprehension, the scores from Study II indicated a consistent relationship between juveniles' exposure and performance. Youths with two or more prior felony referrals had significantly higher Function scores than those with fewer referrals. Similarly, adult ex-offenders' scores were significantly higher than those of nonoffenders (when IQ, race, and age differences were statistically controlled). This suggests that greater experience leads to a better understanding for both juveniles and adults of the role and significance of the Miranda rights within the legal system.

For both samples, age and IQ continued to be related to performance.

\section{Juvenile Performance Measured Against a Relative (Adult) \\ Criterion: Two-Way Analysis of Variance for Age and IQ}

In Study I, a two-way analysis of variance for age and IQ was performed, thus permitting a comparison of Function scores for persons of various ages with similar IQ levels. The scores of ten- to thirteenyear-olds were significantly below those of fifteen-year-olds, whose scores were significantly below those of seventeen-year-olds. The scores of fourteen-year-olds were significantly below those of sixteenyear-olds, whose scores were significantly below those of twenty-yearolds. Thus, as a group, juveniles below the age of fifteen demonstrated significantly poorer understanding of the function and significance of the rights to remain silent and to counsel than did the members of any of the adult age categories. Sixteen-year-olds, however, nranifested a level of understanding similar to that exhibited by seventeen- to nineteen-year-olds.

The differences in the Function scores between juveniles and adults were significant within every IQ classification; the differences were most marked when comparing low IQ juveniles to low IQ adults. ${ }^{95}$ Thus, there is a clear distimction between the abilities of

94. See note 114 infra.

95. For example, at IQ scores of 70 or below, the mean Function score for juveniles was five points lower than that of adult ex-offenders (about 1.5 standard deviations below the adult mean). In contrast, at IQ scores above 100, the juvenile mean Function score was only 2.5 points below the adult mean (less than one standard deviation below the adult mean). 
younger juveniles and adults to understand the content of the Miranda warning and to perceive the function and significance of the rights it sets forth.

\section{Summary}

The results of Study I and Study II support the following conclusions regarding juveniles' abilities to waive the rights to remain silent and to legal counsel conveyed by standard Miranda warning statements and hypothetical interrogation situations.

(1) As a class, juveniles younger than fifteen years of age failed to meet both the absolute and relative (adult norm) standards for comprehension measured in Study I and in Study II. The vast majority of these juveniles misunderstood at least one of the four standard $M i$ randa statenients, and compared with adults, demonstrated significantly poorer comprehension of the nature and significance of the Miranda rights.

(2) As a class, fifteen- and sixteen-year-old juveniles with IQ scores below 80 also failed to ineet both the absolute and relative standards.

(3) As a class, sixteen-year-olds (and, nore equivocally, fifteenyear-olds) ${ }^{96}$ understood their rights as well as seventeen- to twentytwo-year-old adults. It should be noted that between one-third to onehalf of fifteen- to sixteen-year-olds with IQ scores above 80 exhibited madequate comprehension using the absolute criterion, however.

(4) Juveniles' sex and socioeconomic status were not significantly related to coniprehension of the Miranda rights. Race was related only among juveniles with low IQ scores, black juveniles having poorer $M i$ randa comprehension.

(5) Prior court experience bore no direct relation to understanding the words and phrases in the Miranda warning. However, it was related to mcreased understanding of the function and significance of the rights to remain silent and to counsel.

\section{IV}

\section{The Need for a Per Se Approach}

\section{A. Younger Juveniles}

The studies indicate that as a class, juveniles younger than fifteen do not understand at least some of their Miranda rights. Since the members of this group failed to exhibit the minimuin level of under-

96. The 15-year-old category performed significantly more poorly than 17- to 21-year-old adults on the Rights and Function tests, but not on the Vocab measure. 
standing required by the studies, their waivers cannot be considered meaningful; to hold otherwise would render ineffective the juveniles' rights to remain silent and to counsel by giving effect to waivers unknowingly made. Moreover, the project findings are bolstered by the fact that while the research subjects were questioned under optimal circunnstances, juveniles actually interrogated by the police would not be immune from comprehension inhibitions that stem from a pressurepacked setting. The inescapable conclusion, therefore, is that juveniles younger than fifteen years old require soine form of assistance if they are to waive their rights knowingly.

Given Gault's adınomition that the "greatest care"97 must be exercised in considering waivers nade by juveniles, it seems unwise for the juvenile justice systein to continue to submit this identified class of juveniles to the potential inconsistencies encouraged by the totahity approach. Special safeguards, the absence of which will trigger exclusion of a waiver, should be adopted. While a per se approach will not necessarily eliminate all uncertainty and inconsistency, ${ }^{98}$ its restriction of the judicial role to the determination of several minimal criteria-e.g., whether a preinterrogation conference between a juvenile and an interested adult was held in private ${ }^{99}$-decreases the possibility of an unfounded determination. Moreover, the criteria theinselves provide more objective grounds ${ }^{100}$ than the juvenile's state of mind and can be satisfied more consistently than a "gut level" determination. ${ }^{101}$

There are at least four different ways to structure a per se exclusionary rule such that judicial criteria could be developed. These alternatives mclude (1) requiring the use of standarized, simplified Miranda warnings for younger juveniles, (2) requiring preinterrogation screening of younger juveniles to determine whether they have adequate $M i$ randa coinprehension, (3) requiring the presence of a legally untrained "imterested adult" during interrogation, and (4) requiring the presence of counsel during interrogation. Of these proposals, the requirement

97. 387 U.S. at 55.

98. See Comment, The Judicial Response to Juvenile Confessions: An Examination of the Per Se Rule, supra note 2, at 681-84.

99. See notes 39-43 and accompanying text supra.

100. Many of the criteria are not subject to inconsistent interpretations. Whether a conference was im private and whether an adult was informed of a juvenile's rights admit of straightforward detcrmination.

101. See, e.g., Commonwealth v. Darden, 441 Pa. 41, 43-48, 271 A.2d 257, 258-60 (1970), decided prior to Pennsylvania's adoption of per se rules. The decision was based, in part, ou an assessinent of the juvenile's deineanor. The young suspect was interrogated without the assistance of an adult from 11:10 p.m. until 3:45 a.1n., at which time he confessed; intelligence testing established that he was mildly retarded. The Pennsylvania Supreme Court affirmed the lower court's finding that the waiver was voluntarily made, noting that the juvenile had never denied being read his rights and appeared "remarkably alert, aware and responsive." Id. at 48 n.3, 271 A.2d at 260 n.3. 
that counsel be present affords the best protection for juveniles under the age of fifteen.

The first alternative would be to require that younger juvenile suspects receive a standardized "juvenile Miranda warning." 102 Waivers made by these suspects would not be valid unless preceded by an extensive, simply worded, uniform explanation. While standardization would lielp insure proper police conpliance with the warning requirement, the implementation of such a warning would pose two problems. First, it would be difficult to formulate a warning that could convey adequately the significance of the Miranda rights to a child completely unfamiliar with then1. ${ }^{103}$ Second, even an extensive explanation would not diminish the potentially intimidating nature of a police interrogation to which children are particularly susceptible. Thus, this particular exclusionary alternative does not appear fruitful.

The second alternative would be to institute a preinterrogation screening process to identify the few juveniles under fifteen years of age capable of understanding their Miranda rights. Although this approacl avoids the need for a blanket exclusionary rule, it is impractical. Given the around-tlie-clock nature of police investigative activities and the need for trained testnig technicians, screening prior to interrogation is not feasible. Equally important, the empirical Miranda comprehension measures used in the instant project are not suited to actual interrogation circumstances; they were not devised to detect or to protect against a subject feigning incapacity. While juveniles in the experiniental settimg liad nothing to gain by making poor scores, the same would not be true for juveniles in a screening situation. ${ }^{104}$ Most signifcant of all, however, is that a screening procedure would invite juveniles to waive the very rights that the screening was designed to protect. That is, in order for the police to be permitted to administer the screening, juveniles would have to be informed of, and then waive, their rights to remam silent and to counsel. This, of course, would defeat tlie whole purpose of advance testing.

The third alternative would be to require the presence of a lay-

102. While nonstandardized warnings, couched in terms juveniles can understand, could conceivably raise the level of coinprehension annong younger juveniles, the pohice cannot be expected to know how to tailor their presentation to juveniles of varying levels of intellectual and verbal ability.

103. A recent study found no significant differences in the levels of understanding between a group of juveniles who received the custoinary Miranda warnings and a group who were read a simplified, more explanatory version. S. Manoogian, Factors Affecting Juveniles' Coinprehension of Miranda Warnings (1978) (unpublished Ph.D. dissertation, St. Louis University). This study employed the same rights measure that was used in the studies reported in this Article.

104. Similarly, if a testing measure were used after a confession to assess a juvenile's comprchension, the youth would have a great incentive to perform poorly, particularly if afforded the opportunity to consult with an adult prior to the testing. 
man, such as a parent or guardian, during the interrogation of a young juvenile. This "interested adult's" advice would enhance the juvenile's comprehension, while his presence should alleviate the oppressive nature of the interrogation. Moreover, the requirement that the adult be present would impress upon the police the importance of securing coinpetent advice for juvenile suspects and of making certain that the suspect's waiver is intelligently made.

The most serious objections to this alternative concern the ability of laymen to provide effective assistance in a preinterrogation setting. Commentators have observed that many parents do not care, ${ }^{105}$ and that "often the parents are, at best, only equal in capacity to the child and therefore poorly equipped to comprehend the complexities confrontmg thein."106 In one recent empirical study, nearly three-quarters of a sample of parents disagreed with the premise that children should be allowed to withhold infornation from the police when suspected of a crime. ${ }^{107}$ In anotlier study, nore than two-thirds of the parents present during actual preinterrogation waiver proceedings offered no comments or advice to their children. ${ }^{108}$ When these findings are coupled with those of the instant studies, which indicate that many adults do not themselves adequately understand their Miranda rights, ${ }^{109}$ the "interested adult" alternative becoines even less attractive.

The fourth alternative would be to require that young juveniles have a nonwaivable right to counsel. Mandating that a defense attorney be provided, without request, to assist in preinterrogation waiver proceedimgs is a feasible and effective means of protecting juveniles under the age of fifteen. The attorney would assist the youth in assert$\mathrm{mg}$ his rights and would help to ensure that a waiver or confession, if made, is voluntary and knowing.

Althougl this proposal is not immune froin criticism, it represents the best available remedy. In the first place, mandating legal assistance for young juveniles would not unduly hamper police activities in investigatimg serious offenses, since the more serious offenses will probably be perpetrated by the older juveniles. Secondly, while defense counsel would almost always advise a client to renain silent until the attorney has had the opportunity to review the case fully, the per se proposal would not always reduce the ainount of infornation the pohice acquire about juvenile offenses. In soine instances, the lawyer might assist the

105. M. Paulsen \& C. Whitebread, supra note 4, at 93.

106. McMillan \& McMurtry, supra note 44 , at 570 .

107. Grisso \& Ring, Parent's Attitudes Toward Juveniles' Rights in Interrogation, 6 Crim. JUST. \& BEHAVIOR 211 (1979).

108. T. GRISso, supra note 11 , ch. 8.

109. See Tables 1 and 2 supra. 
suspect to explain clearly his noninvolvement in the incident; in other cases, the lawyer might help the juvenile make a statement that is not susceptible to an inaccurate or adverse interpretation by the pohice. At all events, since information gathered from police interrogations of juveniles is often inaccurate and therefore useless, ${ }^{10}$ the proposed per se rule could only serve to increase the accuracy of any information imparted.

Finally, the ability of lawyers to represent juveniles' interests has been questioned. ${ }^{11}$ Moreover, many juvenile courts continue to perceive defense attorneys as court assistants rather than as legal advocates. ${ }^{112}$ Nevertheless, the beneficial effect of a per se requirement of counsel in juvenile waiver proceedings should be enhanced as the juvenile justice systen increases its own support of a strong advocacy role for these attorneys. At a minimum, the requirement provides a reasonable level of protection for younger juveniles; without this protection, they would be subjected to the very circumstances that Miranda sought to eliminate.

\section{B. Older Juveniles}

While for juveniles younger than fifteen a per se rule is inherently justified by their inadequate comprehension, for older juveniles justification for such a rule must come from extrimsic considerations. Many fifteen- and sixteen-year-old juveniles, particularly those with IQ scores below 80 , had no greater Miranda comprehension than the younger

110. The potential unreliability of confessions by juveniles was a central concern in Gaul's decision to provide special protections for juveniles in interrogatious. The Court noted: "The principle. . upon which a confession may be excluded is that it is, under certain circuinstances, testimonially untrustworthy . . . '" 387 U.S. at 45 (quoting 3 J. WIGMORE, EvIDENCE \& 822 (3d ed. 1940)). The Court then noted: "With respect to juveniles, both common observation and expert opinion emplasizes that the 'distrust of confessions inade in certain situations' to which Dean Wigmore referred ... is imperative in the case of children from an early age through adolescence." Id. at 48. Stating that "authoritative opinion has cast formidable doubt upon the reliability and trustworthiness of "confessions' by children," $i d$. at 52 , the Court cited several cases in which inconsistencies in juvenile confessions had led other courts to recognize the unrehability of the confessions. Id. at 48-55. See In re Four Youths, Nos. 28-776-J, 28-778-J, 28-783-J, 28-859J (Juv. Ct. D.C., April 7, 1961); Ex rel. Carlo and Stasilowicz, 48 N.J. 224, 225 A.2d 110 (1966); In re Gregory W. and Gerald S., 19 N.Y.2d 55, 224 N.E.2d 102, 277 N.Y.S.2d 675 (1966).

111. Cf. Genden, Separate Legal Representation for Children: Protecting the Rights and Interests of Minors in Judicial Proceedings, 11 HARv. C.R.-C.L. L. REv. 565, 590 (1978) (attorneys often lack necessary special skills); Landsuan \& Minow, Lawyering for the Child: Principles of Representation in Custody and Visitation Disputes Arising from Divorce, 87 YALE L.J. 1126, 1158-59 (1978) (greater risk of communication breakdown).

112. W. Stapleton \& L. Teitelbaum, In Defense of Youth $37-39$ (1972); Kay \& Segal, The Role of the Attorney in Juvenile Court Proceedings: A Non-Polar Approach, 61 GEo. L.J. 1401, 1413 (1973). According to one study, many defense attorneys reported to the court their clients adinissions of guilt even though the admissions were given in confidence. Fcrster, Courtless \& Snethen, supra note 64 , at 388 . 
juveniles. ${ }^{113}$ As a class, however, fifteen- and sixteen-year-olds performed significantly better. The performance of this group of older juveniles did not differ significantly from that of the adults. However, that the two empirical studies indicate that the comprehension levels of older juveniles are comparable to those of adults does not necessarily mean that older juveniles should be treated as adults. In fact, there are compelling arguments for waivers inade by older juveniles, like those of their younger counterparts, being subject to an exclusionary rule.

First, the studies only addressed juveniles' coinprehension of the Miranda rights and perception of their significance. They did not measure juveniles' abilities during actual interrogation proceedings, nor did they test juveniles' capacities to withstand intimidating police questioning. Given the einotionally charged circuinstances that older juveniles actually face, courts must, at the least, continue to heed Gault's admonition that their waivers receive special consideration.

Second, given that adults inanifested inadequate understanding relative to an absolute criterion, ${ }^{114}$ it is doubtful that an "adult" level of understanding is the appropriate standard to use in evaluating older juveniles' coinprehension. ${ }^{115}$ Rather, since fifteen- to sixteen-year-olds themselves did not adequately understand the Miranda warnings relative to an absolute standard, it would not be unwarranted to extend the per se rule to them.

Third, while per se rules have been attackcd because they provide too much protection to experienced juveniles familiar with the legal

113. A per se exclusion of waivers by 15- and 16-year-olds with low IQ scores cannot be argued for persuasively since it cannot be implenented: preinterrogation screening of intellectual capacity is infeasible. See text accompanying note 104 supra.

114. Nearly one-quarter of the adults received zero points of credit (indicating inadequate comprehension) on one or more Rights items; over one-third attained zero points of credit on one or hore Vocab items. Furthermore, over $40 \%$ of the adult ex-offenders misperceived the extent to which the right to silence provides protection throughout all later proceedings.

The study's finding that a significant proportion of adults do not understand their rights when read the Miranda warning has potentially far-reaching ramifications. The results indicate that many courts give effect to adult waivers that are made without knowledge of the consequences. The appropriate judicial or legislative response to this situation is not as clear as the response to the juveniles' problems. One possibility is to use the results of this study in an attempt to inake the Miranda waming inore comprehensible. The warning could use simpler language to convey the meanings intended. The warning could also stress that the right to remain silent extends to all aspects of the legal process and that invocation of the right in no way incriminates the defendant. However, the viability of an expanded explanation is subject to doubt. See note 103 and acconpanying text supra. Attorneys and the courts also could better evaluate the quality of adult waivers.

115. This observation does not change the logic or conclusions related to the need for a special per se rule for juveniles under age 15. Whatever the inadequacies of understanding demonstrated by the average adult, younger juveniles as a class manifested significantly lower understanding. 
system, ${ }^{116}$ the instant studies indicate that there is no strong relationship between a juvenile's prior court experience and his coinprehension of Miranda warnings. Consequently, the vahdity of this objection to per se exclusionary rules for waivers of older juveniles is limited. ${ }^{117}$

\section{CONCLUSION}

The two empirical studies described in this Article indicate that younger juveniles as a class do not understand the nature and significance of their Miranda rights to reinain silent and to counsel. Consequently, their waivers of these rights cannot be considered intelligently, knowingly, and voluntarily made. Compared with that of adults, the comprehension of these rights by younger juveniles is so deficient as to inandate a per se exclusion of waivers made without legal counsel by these juveniles. While older juveniles generally understand their rights as well as adults do, the results indicate that an adult level of understanding is an imperfect standard for determining the adequacy of older juveniles' coinprehension. To properly protect the rights of older juveniles as well, per se exclusionary rules should be considered.

116. See notes $47-48$ and accompanying text supra.

117. Prior court experience among juveniles was not related to Miranda warning comprehension (Study I). However, it was related to understanding of the function and significance of the rights (Study II). See text following note 94 supra. 